\title{
Research on Development Strategy of Sports-tourism -- Case Study of Heilongjiang Province \\ Zhao Yang ${ }^{1, a}$ Wang Jiaxing ${ }^{1 b}$ \\ ${ }^{1}$ Tourism and Cuisine School of Harbin University of Commerce, Harbin, China \\ aemail:zhaoyang99@126.com \\ bemail:1395004572@qq.com
}

\section{Keywords: Tourism industry, Sports-tourism, Heilongjiang province}

\begin{abstract}
As a newly developed tourist activity, sports-tourism has been paid great attention all over the world and become a important component of tourism development in recent years. Heilongjiang province is abundant in sports-tourism resources, which is the natural advantage to develop sport-tourism. The paper takes Heilongjiang province as an example, on the basis of analyzing current problems that block tourism market progress in this province, to discuss developing strategy of sports-tourism industry in this province.
\end{abstract}

\section{Introduction}

Sports-tourism is a new type of tourism industry, which is a combination of sports industry and tourist service. Sports-tourism has both characteristics of tourism, such as being allopatry, temporary, consumptive and casual, and the charming of sports activities, like popularity, fitness, being participatory, professional and challenging. Therefore, sports-tourism can satisfy both the pursuit of tourist experience and the require of tourism development of our country. It has a high degree of industrial linkage and strong economic driving effect, which is an important force to promote regional economic development.

Generally speaking, sports-tourism is a kind of consumer behavior appeared at a certain level of people's living standard. Much more specific requirements are made by the market for sports tourist products, service quality and so on. In recent years, the domestic consumption growth in health, fashion and entertainment has been greatly improved under the new normal of economic development in China. Chinese people get more chances to select different methods of fitness, health preserving and sports. New features of economic and social development appear, such as relying on consumption stimulation and service driving, which makes it more important to expand effective investment and consumption in sports, tourism, and other life service industry. All of these provide broad space and good opportunity for the development of sports tourism.

\section{The current problems of sports-tourism in Heilongjiang province}

Heilongjiang province is rich in ice and snow resources in winter and ecological resources in summer, which is the absolute advantage to develop sports- tourism industry. Governor Lu Hao has pointed out the key areas to develop sports industry in Heilongjiang Province, and stressed: " Developing sports industry must have real understanding and conscientiously implement for the deployment of central government on structural reform of supply front whose core principles is to find demands, organize elements, and to provide supplement", which is also the key point to the development of sports-tourism industry in Heilongjiang province."Sport+" mode of tourism in Heilongjiang province started from the year of 2016[1]. The provincial tourism industry entered a new phase. But, there are some obstacle factors that block the development of sports-tourism industry in Heilongjiang province.

\subsection{Defective management system and regulations}

At present, the management system and operational mechanism of the sports- tourism industry in 
Heilongjiang province still need to deepen the reform, the research capacity on sports-tourism is not large enough to form a complete set of policy and system, sports attractions management system is not sound, affecting the development of the industry.

\subsection{Imbalance structure}

The coordinated development of sports-tourism industry in Heilongjiang province is insufficient, tourist projects are mainly concentrated in winter sports with a few projects in summer, which cannot meet the needs of tourists for all year round. The structure of winter items are imbalance with the structural shortage of top class products and structural surplus of medium and low level products.

\subsection{Backward mechanism}

The development of sports-tourism in Heilongjiang is still dominated by the government, relying on the governmental financial support. The development mechanism is relatively backward, the subjective initiative of market operators has not been encouraged, and the level of marketalizational management of capital is still low[2].

\subsection{Narrow marketing channels}

With the fierce competition in sports-tourism at home and abroad, the marketing channel is narrow, lacking of publicity, which is an urgent issue that must be solved as soon as possible. The marketing channels of sports-tourism in Heilongjiang need to be further broaden, in order to meet the consumers' demands. The brand awareness of current sports-tourism products in Heilongjiang has not been established yet.

\section{Development strategies of sports-tourism in Heilongjiang province}

\subsection{To convert ideas and plan industry layout of the province}

Ideas determine the way out. Under the background of current economic transformation and upgrading, the contribution of consumption to economic growth rate continues to increase; at the same time, people pay more attention to health, leisure, and improving quality of their lives. Their travel demands have changed from the low level of traditional sightseeing trip to experiencing tour of complex quality, tourists prefer to participant and experience during the trip instead of watching, hearing. Sports-tourism does focus on physical activity participation and stimulating, which does meet the diversity of different tourists travel demands. Consequently, the overall layout of the sports-tourism development pattern in Heilongjiang province oriented by government, based on the industrial convergence, do promote the development of both sports and tourism industries[3].

Heilongjiang has advantage in geography, good traffic conditions and the unique natural and humanistic resources for developing sports-tourism. The events as Winter Olympics success in 2022, rejuvenating the old industrial bases and the "The Belt and Road" construction brought era opportunities for sports-tourism development in Heilongjiang province. According to the specific conditions, ice and snow sports-tourism should be the first choice and the base in Heilongjiang province, with an emphasis on leisure health tourism. Harbin, the capital city should be the core center, several tourist zones will be constructed in the whole province: Harbin-Mudanjiang-Suifenhe ice and snow sports tourism zone, Harbin-Daqing-Qiqihaer folk sports tourism zone, Harbin-Yichun ecological outdoor tourism zone, Harbin-Jiamusiwater leisure tourism belt and Heilongjiang-Wusuli River international sports-tourism zone, etc. Heilongjiang province will be well-known sports tourism destination both to the domestic and foreign markets.

\subsection{To innovate mechanism and optimize developing model}

Any rising economy can not be developed without the government's support and encouragement. Sports-tourism is a strong relevant industry that not only connects the sports industry and tourism industry, but relates to many other sections as real estate, industry and commerce, finance, environmental protection, insurance, aviation, maritime, and so on. Therefore, the development of sports-tourism industry needs the coordination and support of the government. The local government may introduce relevant policies and regulations to improve the coordination and management mechanism of sports-tourism development, to help constructing cooperation exchange platform for convenience of communication between companies and related departments. 


\subsection{To discover demand and create market}

Ctrip.com issued the first report on Sports-tourism in China in the year of 2016, which indicated that the market share of sports-tourism had been less than $5 \%$ of the total tourist market while the number had reached at $20 \%$ in foreign countries. And according to the investigation and statistics from LY.com, only $8.4 \%$ of the respondents took part in sports tour while $46.8 \%$ of the respondents knew nothing about sports-tourism at all. Thus, sports-tourism is still a new phenomenon in the consumer field. It takes time and process to develop and cultivate sports- tourism market in Heilongjiang province. To develop sports-tourism doesn't mean to simply sell tourist products related to sports to customers, it must be carried out on the basis of fully understanding the characteristics of its consumption and market demands. Tourist products must be designed according to consumption characteristics and psychological preference, as well as tourism regional characteristics of consumers.

\subsection{To improve supply and establish a brand}

The product is the core and key of the development of the tourism industry. To innovation and development of sports-tourism industry in Heilongjiang Province, the core products should be planned in diversification and systematization methods. The products can improve the tourists' experience and participation. A brand must be established with expanding marketing channels, building online stereo platform, and improving the product supply chain of sports-tourism.

\subsection{To improve technical level and enhance the sales}

Tourism has entered the individualized and Internet era, the sports-tourism marketing must cater to demands of different consumers and use a variety of marketing methods. At present, with the rapid development of information technology, the network has penetrated into all aspects of people's social life. But at present, marketing channel of sports-tourism in Heilongjiang province is narrow with very weak market influence. To broaden the marketing channel is one of the problems to be solved urgently. On the basis of reforming informatization of sports-tourism in Heilongjiang province, people who are in charge of designing products and marketing should seek value-added process mechanism and operation on information platform in order to change the present situation of high service cost and insufficient value-appreciation in Heilongjiang sports-tourism industry. In addition, effective and positive promotion has a special significance to traditional sports-tourism product development, which is the effective connection between the traditional sports tourism product and potential tourists.

\section{Acknowledgment}

This research was financially supported by the Discipline project of Harbin University of Commerce: Study on the modern service industry to support Longjiang revitalization (Grant NO.hx2016001).

\section{References}

[1] Cui Yingbo, Gu Huazheng, ect. Research on the Current Situation and Sustainable Development of Ice-Snow Sports Tourism in Heilongjiang Province, China Winter Sports, vol.36, pp. 78-83, 2014.

[2] Bai Lin, Wang Wei, Cong Peicai, Study on Sports Tourism Development with the Background of Supply-front Reform, Journal of Social Science Jiamusi University,vol.35, pp. 58-60, 2017.

[3] Lu Changbao, Guo Xiaofang, Wang Chuansheng, Research on Innovation of Sports Tourism from the Perspective of Value Co-creation, China Sport Science, vol.35, pp. 25-33, 2015. 